\title{
Серийные убийства
}

\author{
ю. М. АНТОНЯн
}

Всероссийский научно-исследовательский институт МВД России, г. Москва, Российская Федерация

ORCID: https://orcid.org/0000-0002-0030-3031, e-mail: antonyan@yandex.ru

\section{Р е фер ат}

Введение: статья посвящена характеристике весьма опасных преступлений, которые могут носить как сексуальный, так и несексуальный характер. Приводятся основные характеристики серийных убийц, особенно сексуальных, предпринимается попытка объяснения их преступного поведения. Цель: раскрытие внутренних причин совершения названных преступлений через мотивацию преступников с учетом внешних способствующих факторов. Выбор именно мотивации закономерен, ибо в мотивах заключены побудительные силы поведения, его личностный смысл, то есть то, ради чего совершаются преступные действия, в чем их субъективная выгода для индивида. Обсуждение: изнасилования и убийства, совершенные с особой жестокостью, насилие над детьми и причинение им тяжких увечий, различного рода сексуальные извращения всегда вызывали естественное отвращение и нежелание заниматься непосредственным изучением личности виновных. Статья основана на изучении личности и поведения преступников, осуществленном автором лично. Результаты: выделены основные черты, определяющие специфику серийных убийств, такие как частота / периодичность совершения преступлений; клишированность самих преступных действий; совершение в условиях неочевидности; проявление особой внешне ничем не мотивированной жестокости. Раскрыты и классифицированы причины серийных убийств: потребность мести; способ самоутверждения; с целью сокрытия следов иных преступлений; для очищения общества от аморальных личностей, позорящих человеческий род, грязных и ненужных; психологическая зависимость от собственного поведения; связь с некоторыми религиозными культами.

К люче вы е слов а : убийство; изнасилование; серийные сексуальные убийства; личность и причины серийных сексуальных убийств.

12.00.08 - Уголовное право и криминология, уголовно-исполнительное право.

Д ля ци ти ро в ан ия: Антонян Ю. М. Серийные убийства. Пенитенциарная наука, 2021, т. 15, № 4 (56), с. 721-732. DOI 10.46741/2686-9764-2021-15-4-721-732.

\section{Serial Murders}

\section{YURII M. ANTONYAN}

All-Russian Research Institute of the Ministry of Internal Affairs of the Russian Federation, Moscow, Russian Federation

ORCID: https://orcid.org/0000-0002-0030-3031, e-mail: antonyan@yandex.ru

\section{Abstract}

Introduction: the article is devoted to very dangerous crimes that can be both sexual and non-sexual in nature. It provides key characteristics of serial killers, especially sexual ones, and discloses their criminal behavior. Purpose: uncovering of internal causes of such offenses through criminals' motivation and external contributing factors. Consideration of motivation is reasonable, as motives contain motivating forces of behavior, its personal meaning, i.e. what these criminal actions are committed for, what is their subjective benefit 
for the individual. Discussion: rapes and murders committed with extreme cruelty, violence against children and causing them serious injuries, various kinds of sexual perversions have always caused natural disgust, and consequently, unwillingness to engage in direct study of the identity of offenders. The article is based on the study of personality and behavior carried out by the author himself. Results: the author identifies main features defining the specifics of serial murders, such as frequency of committing crimes; cliched nature of criminal acts; crime commission in conditions of non-obviousness; manifestation of a special externally unmotivated cruelty. The researcher classifies causes of serial murders, such as need for revenge; a way of self-affirmation; concealing traces of other crimes; purging humanity of immoral personalities, dishonoring the human race; psychological dependence on criminals' own behavior; connection with some religious cults.

Keywords: murder; rape; serial sexual murders; personality and causes of serial sexual murders.

12.00.08 - Criminal law and criminology; penal law.

F or c it a ti o n: Antonyan Yu.M. Serial murders. Penitentiary Science, 2021, vol. 15, no. 4 (56), pp.721-732. DOI 10.46741/2686-9764-2021-15-4-721-732.

Следует различать два основных вида серийных убийств:

- совершенные по сексуальным мотивам (серийные сексуальные убийства);

- серийные убийства, не связанные с сексуальными мотивами и часто совершаемые некрофильскими личностями.

Вторая разновидность серийных убийств встречается намного реже и главным образом детерминируется ненавистью к людям и некрофильскими побуждениями. Внешне такие преступления кажутся немотивированными или хулиганскими, но на самом деле не являются ни теми, ни другими. Мотивы преступников - ненависть к людям, и у всех из них надо отметить некрофилию, под которой следует понимать стремление к мертвому, желание сделать живое мертвым, заглянуть в то таинственное, что зовется смертью. Таким был битцевский (по названию парка в г. Москве) маньяк Пичушкин, убивавший без разбора мужчин, женщин, детей общим числом около семидесяти, который к тому же силился доказать, что он не пичужка, то есть маленькая птичка, хотя его так дразнили в детстве.

Некрофилом был и серийный убийца Лукьянчук, который представлял собой крайне тревожную личность, вполне обоснованно считая, что его наркомания и алкоголизм порождены именно тем, что он постоянно ждал беды, хотя и не знал, откуда она к нему придет. В социальном отношении он был абсолютно люмпенизированным алкоголиком, давно и навсегда выброшенным за пределы нормального общения. Он проживал с сожительницей (тоже алкоголичкой и, с его слов, с задержкой умственного развития) и ее матерью - инвалидом II группы в связи с переломом ноги, также злоупотреблявшей спиртными напитками. С ними жил еще сожитель последней, Криулин, он же соучастник убийств, совершенных Лукьянчуком. Криулин, конечно же, был алкоголиком, дважды сидел в тюрьме и к тому же не имел постоянного пристанища. Жил он тем, что ловил бродячих собак и поедал их (в качестве закуски, разумеется), а шкуры продавал. Куда уходила выручка, догадаться нетрудно.

Первое убийство было совершено Лукьянчуком вместе с Криулиным в 1994 г.

Каждое убийство (и пояснения о нем самого Лукьянчука) рассмотрим отдельно:

1. 10 октября 1994 г. вместе с Криулиным убил неизвестного мужчину, задушив его веревкой, причем инициатором убийства был именно Лукьянчук, он же стягивал веревку на шее жертвы. Криулин помог ему тем, что держал потерпевшего. Труп вдвоем спрятали в канализационном люке, где он и был обнаружен в процессе предварительного следствия.

По поводу этого эпизода Лукьянчук рассказал следующее: «В тот день около 17 часов я пошел за водкой, а когда вернулся, моя сожительница Таня сказала мне, что во время моего отсутствия к нам в форточку стучался какой-то мужик. Сели пить водку вчетвером с Криулиным и матерью Тани. В это время раздался стук в дверь. Таня посмотрела в глазок и сказала, что пришел тот самый мужик, который стучал в форточку. Я взял веревку, Криулин - нож. Открыли дверь, Криулин сразу ударил его рукояткой ножа по голове, тот даже сказать ничего не успел, и я так до сих пор не знаю, что этот человек хотел. Мы сняли с него куртку и пова- 
лили на пол, я накинул ему веревку на шею, хотя мужчина просил его не убивать. Задушил его. Вдвоем с Криулиным выбросили тело в канализационный люк.

Мне давно хотелось убить человека. Все случая не было, а тут он сам пришел (имеется в виду убийство незнакомого мужчины. Ю. А.). Я сказал Криулину, что его надо задушить, а Криулин хотел зарезать. Человек он мне неизвестный, он пришел, чтобы его убили, и его надо было убивать. Я после спать хотел». Он как бы знал, что тот пришел за своей смертью, что его надо было убить. В рассказе Лукьянчука обращает на себя внимание то, что он давно хотел убить человека и убил того, кто не сделал ему ничего плохого, он его вообще не знал и видел впервые, но не сомневался, что его надо убить.

2. 7 декабря 1994 г. Лукьянчук и Криулин выпивали в доме дяди Лукьянчука, где присутствовал их общий знакомый Лосев. Во время выпивки Лукьянчук нанес Лосеву несколько ударов ножом в шею, отчего тот скончался на месте. Вместе с Криулиным труп бросили в тот же канализационный люк, куда и тело неизвестного мужчины.

Об этом эпизоде Лукьянчук рассказал следующее: «Когда выпивали, Лосев сказал, что он судим. Я подумал, как бы он не ударил меня ножом. Поэтому я схватил кухонный нож и два раза ударил Лосева в шею. Я хотел ему голову проткнуть, самого его я как бы и не заметил. Голова его меня интересовала, голова его мне не понравилась. Злость у меня была. Тогда все было неясно. Против Лосева я ничего не имел. У Лосева, может, сердце доброе, он человек хороший».

3. В конце декабря 1994 г. Лукьянчук, Криулин и брат убитого Лосева Анатолий Лосев вновь пьянствовали в доме дяди Лукьянчука. Никакой ссоры между собутыльниками не было. Анатолий Лосев, захмелев, лег на диван и заснул. Лукьянчук стащил его на пол и убил тремя ударами в шею. Вместе с Криулиным труп сбросили в тот же люк.

Об этом убийстве Лукьянчук дал такие разъяснения: «После первого убийства я носил с собой складной нож. Я его взял, чтобы защищаться от друзей убитого мною Лосева. Анатолий меня ни в чем не подозревал, хотя и говорил о желании найти убийцу брата. Как убил Толика, не помню хорошо. Я не подумал, зачем его убиваю. Сам он ниже травы, тише воды. Как объяснить, не знаю».

4. 7 января 1995 г. в доме дяди Лукьянчука в очередной раз была устроена пьянка, в ко- торой приняли участие Лукьянчук, Криулин и Потапов. Лукьянчук начал ссору с Потаповым и нанес ему несколько ударов ножом в шею. Труп с помощью Криулина и своего дяди спрятал в подвал дома последнего. Об этом преступлении убийца сказал: «Лева (Потапов) был дядин сосед, у него я увидел черно-белый телевизор и хотел его украсть. Но телевизор был неисправен».

В том же месяце Лукьянчук пытался убить еще одного собутыльника, ударив его ножом в голову, но тот сумел убежать.

Прежде всего, Лукьянчук является душевнобольным человеком, судебно-психиатрическая экспертиза констатировала у него шизофрению. Однако это не освобождает от необходимости понять эту личность и ответить на вопрос, почему он лишил жизни четверых и посягал на жизнь пятого человека. Душевная болезнь определенно сыграла здесь свою негативную роль, однако, как известно, далеко не все психически больные совершают серию убийств.

Нетрудно заметить, что у Лукьянчука сформировался бред преследования, он очень боялся всего, сам не зная, чего именно, поэтому страх у него носит глобальный характер и, по существу, представляет собой страх смерти. Это некрофилическая, фобическая, замкнутая, дезадаптированная личность, исключительно близко стоящая к смерти; он, с одной стороны, страшится ее, а с другой - непреодолимо стремится к ней. Лукьянчук сказал: «Я помогал смерти... Мне страшно без зла... Я слушался ее призывов убивать». Он ощущал себя слугой смерти. Причем в его больном воображении она принимала образ всеобщего и всепоглощающего зла, однако это зло у него не было с безусловным знаком минус, напротив, судя по его рассказам, оно не обладает зловещими чертами, с ним ему хорошо, и оно ему давало покой. Зло было «постоянно где-то рядом», и он был под его защитой. К смерти его тянуло всегда, поэтому он, по его словам, придушивал пьяных на улице, свою сожительницу и ее мать, но тогда еще мог контролировать себя и по этой причине не носил с собой нож.

Особенно красноречивы слова Лукьянчука, связанные с первым убийством: «Человек мне неизвестный, он пришел, чтобы его убили. Ждешь-ждешь, вот он и пришел, и его надо убивать». Создается впечатление, что Лукьянчук выполнял свою вполне определенную обязанность или, во всяком случае, 
нечто очень важное и давно задуманное. Поэтому иначе он поступить не мог. Так ему было необходимо, так ему было предписано. А человек неизвестный так и остался неизвестным следствию и суду: его похоронили, не обнаружив при нем никаких документов. Он ведь, полагал Лукьянчук, пришел для того, чтобы его убили, а для этого не нужны документы. Вопрос «Кто он такой?» убийца считал излишним - главное, его надо было убивать. У несчастного не было иного смысла приходить, как только чтобы быть убитым.

Что представляет собой зло в понимании, точнее предощущениях, Лукьянчука? Сам он не смог (или не захотел) дать определение. По-видимому, это некая психологически помогающая ему сила или, скорее всего, сама смерть. Во всяком случае, это нечто, что выходит за пределы его личности и в то же время обретается в ее рамках. Очень схожую позицию занимает сам Лукьянчук: он одновременно и в этой, и в той жизни. Жизнь вне утробы, то есть обычная жизнь, для него есть смерть, а собственно жизнь может быть только в утробе, то есть до рождения, идеальное место для него только в материнском лоне. Функции этого лона исполняет для него тюремная камера, обеспечивающая безопасность и уют. Истинную радость и душевный подъем он испытывает, когда узнает об убийствах и других криминальных фактах. Можно полагать, что именно смерть другого (или других) вызывает в нем радость. Это существенное обстоятельство, еще раз дающее возможность говорить о Лукьянчуке как о некрофильской личности, живущей в своем особом мире между жизнью и смертью.

Не зная психологии виновного в посягательстве на половую неприкосновенность, невозможно понять, почему он это сделал. Отсюда следуют нерешенность многих криминологических, криминалистических, экспертных, исправительных и других проблем, почти полное отсутствие научно обоснованных предложений и рекомендаций по профилактике и раскрытию этих преступлений, исправлению виновных. Есть еще одно обстоятельство, препятствующее глубокому познанию половых правонарушений: кроме того, что для изучения такого рода преступлений требуются специальные знания и навыки применения тонких методик, эти правонарушения сами по себе, в силу своего характера и тяжести последствий, нередко как бы отталкивают от себя исследователя.
Изнасилования и убийства, совершенные с особой жестокостью, насилие над детьми и причинение им тяжких увечий, различного рода сексуальные извращения всегда вызывали естественное отвращение и нежелание заниматься непосредственным изучением личности виновных.

Уместно отметить, что половое поведение, пусть и преступное, как и сексуальная жизнь человека в целом, относятся к числу самых больших и загадочных тайн природы, общества и личности и, возможно, нигде, как в такой жизни, столь сложно и тесно не переплетаются в человеке природные и социальные силы. Сексуальные эмоции, переживания и установки сугубо интимны, скрытны и глубоки, порой драматичны, имеют исключительное бытийное значение. Они оказывают огромное влияние на судьбу человека, подчас круто меняют ее, перестраивают все мироощущение.

Сексуальные отношения множеством невидимых нитей переплетаются с иными связями и ценностями, они часто непонятны для внешнего взгляда и даже необъяснимы, их познанию существенно препятствуют тысячелетние ошибки и заблуждения, страхи и предрассудки, предвзятые и неоднозначные оценки, суеверия и сложнейшая символика. Слишком часто в межполовых отношениях и эмоциях видели источник и сущность человеческой порочности, а отношение к ним колебалось от наготы и цинизма до пуританской стыдливости, замалчивания и даже полного отрицания. Тем не менее секс и сексуальные отношения во всем их многообразии всегда сохраняют свою властную притягательную силу. В качестве объекта изучения они всегда привлекали внимание философов, психологов, юристов, писателей.

Сексуальное насилие как разновидность полового поведения, точнее, его несоциализированная, вандалическая форма, не может быть адекватно объяснено лишь как правовое явление вне широкого контекста сексуальной жизни человека, разнообразных социально-психологических связей и механизмов, роли сексуальности в его жизни.

Главная задача, которую мы ставим перед собой в данной статье, заключается в попытке раскрытия внутренних причин названных правонарушений через их мотивацию с учетом внешних способствующих их совершению факторов. Выбор именно 
мотивации закономерен, ибо в мотивах заключены побудительные силы поведения, его личностный смысл, то есть то, ради чего совершаются данные преступные действия, в чем состоит их субъективная выгода для индивида. Ведь очень часто стороннему наблюдателю представляется, что наступающие последствия в виде уголовного наказания неизмеримо превышают все зримые выгоды от совершенного правонарушения и поэтому, казалось бы, нет никакого смысла поступать таким образом. Однако так только кажется, поскольку самые дикие, гнусные, даже нелепые поступки всегда, подчеркиваем - всегда, имеют свою внутреннюю логику, свое внутренне обоснование, свой психологический выигрыш. А понять это можно, лишь принимая во внимание мотивы поведения.

Многоэпизодные сексуальные убийства бросают дерзкий вызов цивилизации. Причинами резкой реакции на них общества являются их более частое совершение в последние годы, исключительно опасные последствия, множество жертв, в том числе детей, беспомощность полиции в ряде случаев. Необходимо отметить, что аналогичные явления наблюдаются во всем мире, и можно утверждать, что возникающие в связи с этим проблемы актуальны для многих стран.

Сексуальные убийцы, как первобытные охотники, обычно выслеживают жертву, внезапно нападают на нее, приводя в состояние шока, насилуют, с исключительным неистовством наносят множество телесных повреждений, вспарывают грудь и живот, выворачивают внутренности, совершают надругательство над половыми органами, отрезают отдельные куски тела и т. д. Создается впечатление, что на свет вырвались ранее невиданные чудовища, грозные слуги смерти, которым не ведомы никакие общественные установления и человеческие чувства. Это впечатление еще больше усиливается, когда выявляются факты каннибализма - поедания отдельных частей тела потерпевших.

Разумеется, предупреждение и расследование подобного рода преступлений представляет немалую сложность, особенно учитывая тот факт, что их часто совершают люди, которые никогда не привлекали внимание правоохранительных органов и ничем не выделялись среди других. Часто трудно бывает решить, действовал ли во всех эпи- зодах серийных сексуальных убийств один человек или убийц было несколько. Иногда эти преступления совершаются на территории разных регионов, в то же время улики на месте происшествия обнаруживаются сравнительно редко, очевидцев же, как правило, вообще не бывает.

Исследование показало, что так называемые многоэпизодные (серийные) сексуальные убийства включают в себя, помимо собственно убийств путем нанесения телесных повреждений, такие действия, как изнасилование, мужеложство с применением насилия, имиссия (введение полового члена) и введение различных предметов во все естественные отверстия тела (чаще в половые органы), обнажение умерщвленных жертв, мастурбирование на фоне созерцания трупов, коитальные и орально-анальные действия с трупами, отсечение гениталийи (или) молочных желез, введение отрезанных мужских гениталий в естественные отверстия тела потерпевшего, извлечение внутренних органов при помощи различных колюще-режущих предметов и (или) посредством выгрызания или вырывания без применения вышеназванных средств, расчленение трупов, дефлорация (лишение девственности), нанесение телесных повреждений различной тяжести с целью получения сексуального и иного удовлетворения, а также некоторые другие аналогичные действия.

Серийными сексуальными убийствами следует считать два и более факта лишения жизни в связи с сексуальными переживаниями преступника. При этом не имеет значения, кто стал жертвой и какие временные интервалы наблюдаются между отдельными преступными посягательствами, а также то обстоятельство, совершены они вменяемым или невменяемым лицом.

Между тем сексуальные убийства далеко не однородны. Большая часть подобных преступлений совершается по сексуальным мотивам: лишение жизни с целью получения сексуального удовлетворения от самого такого факта либо в связи с тяжелыми переживаниями своих сексуальных проблем, потребностью мести женщинам, утверждением себя в качестве мужчины-самца и т. д. Другая часть таких убийств совершается при подавлении сопротивления жертвы исключительно с целью изнасилования. От самого убийства преступники в этом случае не получают никакого удовлетворения, более того, вполне возможно, что убийство 
даже не входит в их планы, и не исключено, что они сожалеют о смерти своих жертв. В эту группу, конечно, входят убийства с целью соития с трупом: такие деяния составляют особую разновидность кровавых преступлений. Понятие некрофилии, введенное в науку Р. Крафт-Эбингом, было отнесено им как раз к таким преступлениям.

Еще одна группа так называемых серийных сексуальных убийств совершается с целью сокрытия следов изнасилований или других сексуальных действий. Именно эта часть преступлений сопровождается попытками закапывания и сжигания трупов жертв, а также актами их расчленения. В таких случаях преступники, как и все те, кто совершают серийные убийства по сексуальным мотивам и с целью соития с трупом, обладают более или менее выраженными чертами, свойственными некрофилам.

Обращают на себя внимание и те сексуальные убийства, которые совершаются в случаях, когда преступник расценивает те или иные слова или действия женщины как крайне унизительные для себя. Обычно это происходит во время полового акта или непосредственно после него, при этом необязательно этот акт реально носил насильственный характер, а оскорбление действительно имело место. Такие преступления совершаются только по сексуальным мотивам, поскольку преступник болезненно воспринимает слова жертвы именно в отношении его сексуальных возможностей. Он защищает себя как самца.

Подобного рода защитные убийства могут быть и не серийными, а, так сказать, одноразовыми, но все равно их следует относить к сексуальным.

Значительную группу серийных сексуальных убийств составляют те, которые совершаются якобы для очищения общества от аморальных личностей, позорящих человеческий род, грязных и ненужных. Жертвами при этом становятся проститутки и женщины, которые, на взгляд убийцы, ведут безнравственный образ жизни. Таковыми были, согласно представлениям иркутского маньяка Попкова, те женщины, которые употребляют спиртные напитки, по этому признаку он убил 81 чел. Возникает вопрос, являются ли подобные деяния сексуальными, ведь даже сам преступник определяет свою цель как очищение общества. Эту цель называл и Попков, в связи с чем утверждал, что ему незачем каяться, он, иначе говоря, делал нужное обществу дело, тем более что его действия не были связаны с изнасилованиями или сексуальной некрофилией, то есть вступлением в интимную связь с женским трупом. Судя по всему, он убедил и самого себя в благородстве такой миссии.

Прежде всего, названным объяснениям самого убийцы доверять нельзя ни в коем случае, поскольку сразу же возникает естественный вопрос: почему общество избавляется только от плохих женщин, а не от мужчин, среди которых омерзительных личностей более чем достаточно? Версиям самих преступников не следует доверять и по той причине, что они пытаются таким образом оправдать себя, не исключено, что и в собственных глазах. Между тем изучение таких сексуальных убийц показывает, что они мстили женщинам за собственные сексуальные провалы, неумение построить отношения с ними на должном уровне. Постепенно у сексуального неудачника формируется особая психологическая, отчасти бессознательная установка вины женщины и в связи с этим самооправдания, что ему очень нужно.

Следует обратить внимание на то, что далеко не только сексуальные преступные действия могут быть серийными. Ими часто становятся кражи, хищения, мошенничества и другие преступления. Но сексуальные мы всегда выделяем особо, даже если это не убийства, а только изнасилования. Происходит это прежде всего потому, что сексуальная жизнь человека - это особая, какая-то таинственная и будоражащая сфера людского существования, всегда привлекающая к себе внимание. Очень часто серийный преступник, тот же карманный вор или мошенник, попадает в психологическую зависимость от собственного поведения, от которой обычно сам не может избавиться. Но таких преступников не называют маньяками, так обозначают только серийных сексуальных. Происходит это, на наш взгляд, как раз в силу особой значимости сексуальной сферы в нашей жизни. Здесь биологический фактор особенно заметен, он значим и в сексуальных провалах мужчины. Перенос на женщину (женщин) своей вины за сексуальные неудачи вполне естественен, поскольку дает возможность мужчине сохранить свое достоинство, честь как самца и таким образом обеспечить самопринятие, ведь человек стремится принять себя толь- 
ко в определенном качестве. Провалы здесь для него особенно болезненны.

Таким образом, можно сделать вывод, что многоэпизодные сексуальные убийства условно могут быть разделены на пять отдельных групп: 1) убийства, совершенные с целью получения сексуального удовлетворения во время совершения; 2) убийства с целью подавления сопротивления жертвы перед или во время изнасилования; 3) убийства с целью соития с трупом; 4) убийства с целью сокрытия следов преступления; 5) убийства, совершенные в ответ на действия, расцениваемые как унижение; 6) месть женщине за собственные сексуальные провалы.

В науке предложены и иные типологии серийных сексуальных убийств. Так, Г.Б.Дерягин выделяет:

1) убийство как следствие преодоления сопротивления жертвы при попытке изнасилования;

2) убийство в целях лишения жертвы возможности призвать на помощь;

3) убийство в целях обострения сладострастных, сексуальных переживаний (сладострастное убийство);

4) убийство в момент неконтролируемого переживания оргазма (которое надо отличать от упомянутого выше);

5) убийство жертвы (и свидетелей) для сокрытия сексуального преступления;

6) убийство по другим мотивам, напоминающее сексуальное убийство, но таковым не являющееся [1].

Как представляется, эта типология недостаточно полная. Кроме того, непонятно, зачем относить к сексуальным убийства по другим мотивам.

Опираясь на существующие источники, Г. Б. Дерягин отмечает, что число убийств с изначально сексуальной мотивировкой в последние три десятилетия во всем мире постоянно возрастает. При этом они нередко характеризуются серийностью, то есть тем, что число эпизодов достигает двух и более. Этимологически под серией (от лат. series «ряд») понимается последовательный ряд, группа неких сходных, обладающих общим признаком, объединенных одним названием событий. Таким образом, серию убийств надо отличать от двойного или массового убийства, тем более уже второе деяние, как правило, позволяет заметить криминальный почерк убийцы. Возраст сексуальных убийц имеет тенденцию к снижению, а сами сек- суальные убийства - к усложнению. Так, в научной литературе описан случай сексуального убийства, совершенного 13-летним мальчиком, имевшим дисфункциональное семейство и психолого-психиатрические проблемы. Убийство он совершил в процессе сексуального насилия, повторив эпизоды только что просмотренного эротического фильма.

Аналогичные убийства при схожих ситуациях отмечены и другими авторами. Описаны случаи ритуального сексуального насилия, связанные с некоторыми религиозными культами.

Одной из исходных позиций проведенных с моим участием и мною исследований является признание того, что изнасилования и сексуальные убийства есть разновидности полового поведения, точнее, его несоциализированные и наиболее опасные формы. Такие преступления не могут быть объяснены только как правовые явления, вне широкого контекста сексуальной жизни человека, разнообразных индивидуально-психологических и социально-психологических связей и механизмов, сексуальных влечений и потребностей, именно поэтому требуются использование достижений различных наук, проникновение в бессознательную сферу психики. В целом это криминологическое, можно сказать, криминолого-психологопсихиатрическое исследование.

Степень защищенности людей от полового разбоя еще совершенно недостаточна. Между тем любой ущерб, нанесенный им, это покушение и на общество, его нравственность, а поэтому общественное мнение в целом крайне негативно относится к таким посягательствам и всегда требует сурового наказания преступников. Абсолютно нетерпимы факты изнасилования детей и подростков обоего пола, изнасилования женщин, сопровождающиеся их убийством или нанесением тяжких телесных повреждений, особенно в тех случаях, когда подобные деяния совершаются не один, а много раз. Многоэпизодные серийные убийства и изнасилования вызывают широкий и всегда гневный резонанс, о них часто пишут, но в многочисленных статьях и даже книгах очень мало серьезных попыток разобраться в том, почему так случилось, что толкнуло данного конкретного человека на столь кровавое злодеяние.

Все изученные сексуальные преступления были совершены в разных местах, при 
различных обстоятельствах, имели неодинаковое количество жертв и осуществлялись разными способами. Однако можно обнаружить некоторые объединяющие их признаки. К числу важнейших следует отнести то, что, во-первых, практически все они были совершены в условиях неочевидности, во-вторых, сопровождались особой внешне ничем не мотивированной жестокостью и, в-третьих, жертвами этих убийц иногда, хоть и редко, становились двое и более людей. Совершались убийства как в городах, так и в сельской местности.

На территории городов немалая часть преступлений совершалась в каких-либо помещениях (40,6 \% от городских сексуальных убийств). Как правило, таким убийствам в помещениях предшествовало предварительное знакомство убийц и потерпевших с последующим совместным распитием алкогольных напитков. Иногда потерпевшие приводились в квартиру преступника насильно или под воздействием угроз. Помимо мест проживания преступников и жертв эти кровавые деяния совершались и в городских квартирах, принадлежащих их родственникам или знакомым. Остальные подобные преступления были совершены на чердаках, в подвалах, подъездах жилых домов и различных учреждений и предприятий, а также по месту работы жертвы или преступника, в гостиницах, банях.

Эти убийства имели место в городах не только в вышеперечисленных местах. Немалая их часть $(59,4$ \%) произошла вне каких-либо помещений: на улицах города, стадионах, стройплощадках, территориях предприятий и учреждений, в парках, городских лесополосах и лесных массивах, глухих и безлюдных местах, на пустырях, территориях, прилегающих к городским железнодорожным вокзалам и автостанциям.

Здесь преступнику сравнительно легче осуществлять преступные действия ввиду практически полного отсутствия возможных свидетелей, меньше возникает проблем и с сокрытием следов преступления. Подчас попыток сокрытия даже и не предпринимается, если проживание или работа убийцы не связаны каким-либо образом с местом, где имело место противоправное деяние.

Следует заметить, что жертвами, когда нападение происходило внезапно, не всегда были ранее незнакомые женщины. Ими нередко становились те, с кем преступник знакомился за некоторое время до этого.
Так, серийный убийца Чикатило (53 жертвы) завязывал знакомство на железнодорожных и автовокзалах, рынках, а затем под благовидным предлогом уводил в безлюдное место. Он был неплохим психологом и почти безошибочно угадывал одиноких женщин, недальновидных и простодушных.

Если рассматривать отдельно убийства в помещениях, то большая их часть была совершена в квартирах преступников (17,3 \%), квартирах жертв (11,3\%), а также их родственников и знакомых (3,8 \%). Очевидно, здесь немаловажное значение имело то обстоятельство, что в этих случаях жертва и преступник были предварительно знакомы и личность преступника не вызывала особых подозрений у жертвы или в силу различных обстоятельств, например юного возраста, жертва была не в состоянии правильно оценить грозящую ей опасность. Доля остальных городских помещений, выбранных в качестве места совершения преступления, в сравнении с местами проживания преступников и жертв относительно невелика. Как правило, это были единичные случаи, за исключением чердаков, подвалов и подъездов жилых домов - их количество несколько больше (3\%).

Как уже отмечалось, большая часть городских серийных сексуальных убийств была совершена вне каких-либо помещений (59,4 \%). Лидирующее место здесь занимают лесные массивы и лесополосы. Доля преступлений, совершенных в этих местах, наиболее высока (13,5\%); несколько меньше их совершено на улицах городов (12 \%); далее идут пустыри и глухие безлюдные места $(10,5 \%)$ и городские парки (6,8 \%). Убийства, совершенные на стадионах (3 \%), стройплощадках (3 \%), территориях различных предприятий и учреждений (5,3 \%), вблизи железнодорожных вокзалов и автостанций (5,3 \%), не имеют особого распространения, однако происходят и здесь.

Показатели многоэпизодных сексуальных убийств в сельской местности $(42,1 \%$ от общего числа) примерно такие же, как и в условиях города, но с некоторыми отличительными особенностями. В силу специфики инфраструктуры сельского региона убийства здесь совершались в таких местах, как дом жертвы (18,6 \%), дачный дом преступника (1\%), рабочее помещение преступника (7,2 \%), территория агропромышленного комплекса (1\%), границы населенного пункта (8,3 \%), дороги и прилегающие к ним 
территории (6,2 \%), открытые сельскохозяйственные угодья и пространства (15,5\%), лесные массивы и лесополосы (40,2 \%). Как и городские, сельские убийства можно условно разделить на имевшие место в закрытых помещениях и совершенные вне помещений, помня при этом, что на селе место жительства и место работы часто совпадают.

Большая часть сексуальных убийств в сельской местности происходила в лесных массивах и лесополосах. Далее по мере убывания: дома, принадлежащие жертвам, открытые сельскохозяйственные угодья и пространства, места, находящиеся в границах населенных пунктов, дороги и прилегающие к ним территории.

Если взять все серийные сексуальные убийства в городе и сельской местности, то около 9 \% из них было совершено в соучастии.

Некоторые серийные сексуальные убийцы для совершения преступлений готовят специальные помещения, хотя первые нападения случались в других местах.

Большая часть всех серийных сексуальных убийств отличалась применением особо мучительных для потерпевших способов совершения преступлений, хладнокровным доведением преступных замыслов до конца, глумлением над жертвами, циничными действиями, и это особенно отличает их от других тяжких посягательств на человека. Чаще всего наносились множественные колото-резаные и рубленые повреждения, в том числе специально приготовленными и изготовленными предметами, во многих случаях производились ампутация половых органов и других частей тела, вскрытие тела, введение различных предметов в естественные отверстия, расчленение трупов, а в некоторых случаях их сожжение или попытки сожжения. Немалое число преступников с особой жестокостью наносили жертвам многочисленные удары руками и ногами.

Имели место и действия, направленные на облегчение реализации преступных замыслов и устранение препятствий для причинения особых мучений жертвам. Примерами преступлений, сопровождающихся особой жестокостью, выступают такие акты, как термическое воздействие на тела потерпевших и причинение весьма болезненных ощущений колющими предметами без нанесения тяжких телесных повреждений.
Особая жестокость этих убийств проявлялась и в таком сугубо специфическом акте, как введение различных предметов в естественные отверстия тела, главным образом во влагалище.

Что касается способов умерщвления при совершении многоэпизодных убийств по сексуальным мотивам, то здесь необходимо заметить следующее. Подавляющее большинство убийств было осуществлено посредством нанесения жертве тяжких телесных повреждений. Далее по частоте идет удушение жертв руками и при помощи различных предметов (шнуры, одежда потерпевших, постельные принадлежности и т. д.). Незначительное число убийств было совершено с применением огнестрельного оружия, как правило охотничьего.

Небезынтересно будет отметить, что только около 25 \% преступников после убийства присваивали себе ценные, а порой и не особенно ценные вещи потерпевших. Иногда они приобретали для убийцы статус реликвии.

В этом случае происходит фетишизация всех преступных действий и похищаемых предметов, запечатление преступлений. Вещи используются как стимул для фантазирования или извлечения воспоминаний из памяти, что может сопровождаться мастурбацией и достижением сексуального удовлетворения.

Если преступник мстит женщинам за свои страдания и унижения или выступает в качестве чистильщика человечества, жертвы деперсонализируются, они запечатлеваются в его психике как одно лицо. Поэтому он потом не всегда способен опознать потерпевших, в связи с чем фетишизация похищаемых предметов становится еще более актуальной.

Кстати, идея чистки человечества отнюдь не редкость. Известны случаи убийства бродяг и нищих, спившихся людей. Самый заметный из чистильщиков - Гитлер, который не только уничтожал неизлечимо больных и умалишенных в самой Германии, но еще стремился ликвидировать целые народы (евреев, славян, цыган и других), которые считал вредными, опасными и ненужными. Улучшители рода людского были всегда, еще в древности, и это опаснейшие враги человечества.

Еще надо отметить клишированность самих преступных действий, тем более что они серийные. Стереотипность проявляется 
в мотивах поведения, способах нападения и предшествующих ему действиях, в том числе подготовке к нему. Она же обнаруживается в выборе времени и места преступления, конкретных садистских действиях, обращении с трупом, например вскрытии гениталий, поедании их частей, что психологически означает овладение женщиной, сокрытии следов своего поведения и т. д.

Фетишизация, деперсонализация и клишированность свидетельствуют об уменьшении произвольности сексуального преступного поведения, которая усиливается при расстройствах психической деятельности. Поведение становится аддиктивным, человек попадает в психологическую зависимость от него. Каждый акт нападения на женщину позволяет убийце продемонстрировать самому себе господство над ней, хотя и деперсонализированное, но это не имеет для него значения. Главное, он еe хозяин и может сделать с ней все, что угодно, особенно если она мертва. Поэтому господство приобретает сверхценность. Это обнаруживается в пристрастии к литературной и кино-, фотопродукции агрессивно-садистического и порнографического содержания, увлечении анатомией, повышенном интересе к строению женского тела, в особенности женских гениталий.

Проблема сезонности не особенно очевидна для многоэпизодных сексуальных убийств. Большая их часть была совершена в такие летние месяцы, как июль и август, а распределение по остальным временам года носит более или менее равномерный характер. Отчасти это можно объяснить тем обстоятельством, что многие из них совершались в закрытых помещениях.

Одной из характеристик серийных сексуальных убийств является их многоэпизодность. Преступники совершают эти преступления с различной частотой, пределы которой колеблются от нескольких минут до нескольких лет, что может быть обусловлено самыми различными факторами. Условно классифицируя рассматриваемые убийства по временным параметрам, можно разбить их на следующие группы:

1. Серия убийств, совершенных одно за другим с перерывом в несколько минут. Как правило, эти преступления совершаются в городских помещениях преимущественно в отношении детей и лиц, с которыми преступник был ранее знаком.
2. Серия убийств, совершаемых с перерывами в несколько дней или месяцев и длящихся примерно год.

3. Серия убийств, длящихся в течение ряда лет с временными промежутками между эпизодами от нескольких дней до нескольких лет.

Промежутки между отдельными сексуальными убийствами были, естественно, разными у различных субъектов. Однако можно при этом увидеть две особенности. Первая состоит в том, что сначала убийства происходят относительно редко, затем с какого-то момента их частота резко возрастает. Такая закономерность, как учащение преступной активности сексуальных агрессоров с течением времени, говорит о патологическом развитии личности с нарастанием компульсивности, неодолимости влечений. Вторая замеченная особенность свидетельствует о возможности у преступника в определенной ситуации корригировать свое патологическое поведение. Так, Чикатило и Головкин, зная из прессы и телевидения о розыске сексуального убийцы в их местности и понимая, что речь идет о них самих, на некоторое время прекращали свою криминальную активность.

Итак, можно выделить основные черты, определяющие специфику серийных сексуальных убийств: количество жертв - не менее двух; жертвами становятся подростки и дети обоих полов и взрослые женщины; большинство убийств совершается с особой жестокостью; все убийства связаны с сексуальными переживаниями преступника; в большинстве случаев жертва специально не выбирается, нападение часто совершается и на тех, кто просто оказался в данном месте; убийства совершаются с разной периодичностью, разными способами и орудиями, очень редки случаи, когда виновный не доводит преступление до конца по независящим от него обстоятельствам; иногда сексуальные убийства сопровождаются актами каннибализма; все серийные сексуальные убийства совершаются в условиях неочевидности.

Поскольку рассматриваемые убийства являются разновидностью сексуальных убийств, необходимо дать общее определение последних. Сексуальными убийствами мы называем все случаи противоправного лишения жизни, которые связаны с сексуальными переживаниями, сексуальными влечениями или мотивами, даже если имеет 
место расстройство влечений, а еще шире с отношениями между полами.

Таким образом, к сексуальным убийствам мы будем относить те, которые, может быть, и не сопровождались собственно сексуальными действиями, например изнасилованием, но по своему внутреннему содержанию и субъективному смыслу связаны именно с половой жизнью виновного, а еще шире - с его отношениями с представителями другого пола, его биологическим и социальным признанием в такой связи. Чаще всего анализируемые преступления совершают сексуальные неудачники (банкроты), в том числе импотенты, которые винят в этом женщин. Психологически последних объединяют в одно лицо, которое подвергается нападению.

Среди сексуальных убийц, совершающих особо жестокие преступления, можно выделить тех, чьи преступные действия отличаются внезапностью массированного аффективного взрыва: жертве наносится множество телесных повреждений на протяжении более или менее длительного времени. Об особой жестокости прежде всего говорит характер повреждений, их множественность, у потерпевшего не остается ни одного живого места. Целью здесь не обязательно является убийство, хотя чаще всего это происходит, сексуальная мотивация вырастает на почве весьма драматичных ощущений своей сексуальной неполноценности.

На местах происшествий часто можно обнаружить следы рук и ног, транспорта, крови, спермы, слюны (отхаркивания и иная продукция организма). Могут быть найдены следы распития спиртных напитков, куски (лоскуты) одежды, обуви, оторванные пуговицы, окурки папирос и сигарет, волосы. Нужно должным образом оценить сломанные ветви кустарников и помятую траву, если происшествие имело место не в жилом помещении, а в помещении - на пострадавшую мебель.

В редких случаях преступник оставляет на месте происшествия надписи, адресованные полиции. Это говорит о том, что он вступает с ней в противоборство наподобие игр «Казаки и разбойники», «Полицейские и воры». Иногда такие надписи свидетельствуют о том, что преступник устал скрываться и хочет быть пойманным.

Некоторые серийные сексуальные убийства поражают своим сверхизуверским садистским характером.
Начиная с середины 1980-х гг. в подмосковных лесных массивах стали находить трупы мальчиков 10-15 лет со следами зверских пыток, ранений в области половых органов, иногда эти органы были отрезаны, а трупы расчленены. Как было установлено через несколько лет, эти исключительные по бесчеловечности поступки были совершены неким Головкиным, имеющим высшее ветеринарное образование. Ему было 25 лет, когда он убил в первый раз. Его называли Удавом, и с помощью журналистов эта кличка закрепилась за ним.

В 1982 г. Головкин впервые попытался убить в лесу мальчика 14-15 лет. Такие попытки он дважды повторил в 1986 г.: перерезал мальчику горло, совершил с ним сексуальные действия, второго ребенка убил, повесив его на дереве, отрезал половой член с мошонкой, разрезал грудь до лобка, затем отсек голову, ее и половые органы унес с собой. Еще одному мальчику этот сексуальный маньяк и садист нанес 35 ножевых ранений, другого, 10 лет, повесил за шею в своем гараже на скобе, затем вынес труп в лес и там расчленил его, отрезав руки, ноги, голову. В последующем специально для убийств он вырыл в гараже погреб, в котором полностью забетонировал пол, стены обложил бетонными плитами, вбил в потолок лестницу, в стены прочно укрепил кольца, скобы, провел свет. Одну из своих жертв в подвале Головкин после совершения актов мужеложства повесил, затем расчленил тело, спустил кровь в ванну, ампутировал половой член с яичками, пытался съесть мясо, отрезанное с бедра. Примерно таким же путем совершил еще ряд убийств мальчиков с расчленением тел, вырезанием внутренностей, снятием кожи, отрезанием полового органа, а одного несчастного пытал, подвесив на дыбе и опаляя лицо и лобок паяльной лампой. Однажды он убил сразу двух мальчиков, причем одного на глазах у другого, а затем сразу трех: он их пытал, убивал долго и мучительно, стремясь продлить страдания умирающего и тех, кто на него смотрел, расчленяя при них убитых. Во всех случаях Головкин совершал сексуальные манипуляции и получал половое наслаждение, хотя оргазм наступал не всегда.

В том, что это сексуальный серийный убийца, не должно быть сомнений.

Серийные сексуальные убийства в основном совершаются потому, что преступники являются сексуальными банкротами, пре- 
терпевая тяжкие для них поражения даже на стадиях знакомства с женщинами и, конечно, в период половой близости. Таким был Чикатило, на совести которого 53 жертвы, но никого из них он не насиловал, поскольку являлся пассивным гомосексуалистом и импотентом. В его мотивации достаточно отчетливо прослеживается месть женщинам, но еще, как у настоящего садонекрофила, получение сексуального удовлетворения при виде страданий и мучений жертвы. Сексуальные неудачники - наиболее характер- ная фигура среди серийных сексуальных убийц. Заметим, что никто из них никогда не обращался к врачам, и это совсем не случайно: просьба о медицинской помощи есть мощный удар по мужскому самолюбию.

Необходимо отметить, что серийные сексуальные убийства в нашей стране раскрываются очень плохо - отсюда десятки жертв. Начинать во всех случаях надо с экстренных мер по розыску пропавших женщин и детей и не ждать трех суток со дня заявления об исчезновении.

\section{СПИСОК ЛИТЕРАТУРЫ}

1. Криминальная сексология / Г. Б. Дерягин [и др.]. - Москва : ЮНИТИ-ДАНА, 2011. - 399 с.

\section{REFERENCES}

1. Deryagin G.B, et al. Kriminal'naya seksologiya [Criminal sexology]. Moscow: YuNITI-DANA, 2011. 399 p.

\section{СВЕДЕНИЯ ОБ АВТОРЕ / INFORMATION ABOUT THE AUTHOR}

ЮРИЙ МИРАНОВИЧ АНТОНЯН - доктор Юридических наук, профессор, заслуженный деятель науки РСФСР, главный научный сотрудник Всероссийского научноисследовательского института МВД России, г. Москва, Российская Федерация, ORCID: https://orcid.org/00000002-0030-3031, e-mail: antonyan@yandex.ru
YURII M. ANTONYAN - Doctor of Sciences (Law), Professor, Honored Scientist of the RSFSR, Chief Researcher of the All-Russian Research Institute of the Ministry of Internal Affairs of the Russian Federation, Moscow, Russian Federation, ORCID: https://orcid.org/0000-0002-0030-3031, email: antonyan@yandex.ru 